\title{
TRANSFER PRICING A REVIEW OF LITERATURE
}

\author{
Dr. Subha Kant Padhi \\ Professor, Xavier Institute of Management Bhubaneswar \\ Xavier Square, Jaydev Vihar, Bhubaneswar Odisha, India
}

\begin{abstract}
An attempt has been made through this paper to understand the various theoritical models that have been developed to address the transfer pricng complexities and the empirical studies that have been made to understadn the transfer pricing practices in the MNEs over the last six decades. Though the concept of transfer pricng in the modern times can be traced back to early '40s, the models have been developed mostly during the '70s and '80s. The empirical studies started almost from that time as it was practically extremely difficult to adopt any specific model as a transfer pricing problem solving tool.

This study has reviewd the literature from both the aspects - theoritical and empirical. The objective of the study is to findout the scope for further study in this field.
\end{abstract}

Keywords: Transfer Price, Theoritical model, Empirical study, Multinational Enterprises, Tax minimization.

Cite this Article: Dr. Subha Kant Padhi, Transfer Pricing a Review of Literature. International Journal of Advanced Research in Management, 10(1), 2018, pp. 01-07. http://iaeme.com/Home/issue/IJARM?Volume=10\&Issue $=1$

\section{INTRODUCTION}

Following the 1963 convention, almost every author and researcher have tried to give a new or a different dimension to this complex issue. There exists a vast literature on transfer pricing. In this literature survey, the primary focus has been on the issues of adoption of different methods of transfer pricing, the possible manipulations in the methods and the motives behind such creative transfer pricing and profit shifting.

Kenneth J Arrow (1964) in his article titled "Control In Large Organizations" used concepts like 'economic content' and 'form of transaction' to demonstrate that a transaction can be (i) Completely Internal, (ii) Internal but from one enterprise to another under same management or control and (iii) A normal commercial transaction. According to him, the control problem arises on choosing the correct prices in the second scenario, as each manager does want to maximize profit. Copithorne, L.W. (1971) had stated that transfer prices are a set of useful tools in moving profit from one company to another, perhaps via a third company. 
He also echoed the views of Hirshleifer (1954) and mentioned that introduction of taxes on corporate profits as well as some policies of management can drive the transfer prices. The deliberations continued and Lall, S. (1973) tried to reason out the causes that could be compelling a MNE to shift the profit. He considered the impact of effective tax rates on repatriable profits, restrictions on repatriation, price controls on the output in either country, import duties and stability of the exchange rate of the two currencies etc. to be the major inductors for a planned transfer price, which could help in shifting the profit. E.J.R. Booth (1977) with Oscar W. Jensen (1977) tried to build upon the theory of Copithorne, L.W. (1971) and searched for new scenarios under which transfer prices can have implications for profit maximization.

Although the transfer pricing problem became conspicuous more than sixty years ago with the invention of the multidivisional structure (Chandler, 1962), its management is still not well understood (Vancil, 1979, Kaplan, 1982). The problem is manifold, complex and highly time consuming to resolve. Consequently, academicians took interest in it from research point of view while the practisoners followed the regulations with some creative planning without being sure of its accuracy. Vancil (1979) aptly stated that:

"My third disappointment in this study is that I have been unable to say anything definitive or even mildly useful on the subject of transfer prices .... The issue remains a perennial puzzle for academicians, while practitioners continue to cope. I wish the best of good fortune to the next researcher to tackle this problem".

This statement shows the level of difficulty a researcher has to face while doing a research on the transfer pricing subject.

\section{THE LITERATURE}

In this study efforts has been made to broadly classify the literature into two parts $i$. theoretical approach and ii. empirical studies. Each approach has its own strengths and drawbacks. Most of these studies are aimed at finding out a suitable transfer pricing mechanism acceptable to the MNE as well as to the tax authorities. While the theoretical approaches have been developed by the authors based on their understanding of the transfer pricing problem, the empirical studies have been based on the data provided by the MNEs for the same.

\subsection{Theoretical Approach}

The theoretical approach has been broadly classified into five categories by the authors namely:

1. Economic Theory

2. Mathematical Programming

3. Accounting Theory

4. Organizational Behavior Theory

5. Strategic Management Theory

\subsubsection{Economic Theory}

The Hirshleifer (1956) model forms the backbone of economic theory. From the economists side, this was one of the first formal model to be presented to the outer world (Eccles, 1985; Grabski, 1985). One of the major shortcomings of this theory is that it did not address the issue of strategy. 


\subsubsection{Mathematical Programming Model}

Mathematical program model was to dveloped with the intent to findout an ideal transfer price, that provides the best result for the entity in toto (Ecclcs, 1985).

\subsubsection{Accounting Theory}

The transfer pricing approaches based on accounting theory had the same objective as the economic theory and mathematical programming approaches. The first effort to apply Hirshleifer's (1956) theory to accounting was made by Solomons (1965). The accounting theorists, like the economic theorists and mathematical programmers, focused on how transfer prices affect economic decisions (Eccles, 1985).

\subsubsection{Organizational Behavior Theory}

Grabski (1985) noted how unusual it is that only a small amount of research focusing on organizational behavior theory and transfer prices had been published by the mid-eighties. Yet, most of the problems pointed out in the complex mathematical models cited the inability to obtain fully truthful information from divisional managers because their compensation schemes are tied to divisional profits (Kanodia, 1979; Harris, et al., 1982; Ismail, 1982).

\subsubsection{Strategic Management Theory}

The perspective of the whole organization was taken by Swieringa and Waterhouse (1982).

\section{EMPIRICAL STUDIES}

Having reviewed the theoritical approaches, an attempt has been made to determine whether the empirical studies can be matched with theoretical approaches. The demonstration of the income shifting studies is essential in order to uncover limitations, various focuses, limited theoretical bases, methods adopted by previous empirical studies, and provide a justification of the underresearched area of comparables and income shifting in India.

In late '70s, the work of Kim and Miller (1979) made an attempt to empirically understand the various factors that drive the policy decisions relating to transfer pricing in the top US MNEs. They observed from their findings that restrictions imposed by the host nation for repatriation of profits is one of the main facotrs influencing the transfer pricing decision.

Tang and Chan (1979) endeavored to compare the transfer pricing practices of US and Japanese MNEs at both domestic and international levels. They sent questionnaires to the top level finance executives of 300 manufacturing and mining companies selected from the largest 1000 US industrial corporations and to the President of 369 of the largest manufacturing and mining companies in Japan. Responses were received from 145 out of 300 US companies and 102 out of 369 Japanese companies. 76 US companies and 50 Japanese companies responses were useable allowing an aggregate useable response rate of nineteen percent. Their findings indicated that profit mazimization was the most important issue.

Al-Eryani ( 1987 ) identified, tested and explained similarities and differences in transfer pricing motives. Al-Eryani found that the top four ranked environmental determinants for US MNEs operating in more advanced countries (MDCs) and less advanced countries (LDCs) were compliance with US tax and customs regulations, compliance with the tax and custom regulation of the host country, maximization of overall corporate profit, and minimization of overall corporate income taxes.

Wheeler (1988) concluded that improper transfer pricing is the only potential explanation for the differences between the return on assets of US based foreign owned companies and US owned foreign companies 
Kim and Lyn (1990) compared the profitability of foreign-owned companies to those of US owned ones.

Business International Corporation and Ernst and Young (1991) conducted a study to investigate how internal and external factors affect MNES' ITP methodology and policy formulation processes. Ninety-six useable responses were received and interviews with a wide-range of professionals (lawyers, accountants, etc) were conducted.

Both environmental and organizational factors were found to affect/impact respondent firms' TP policies. The two most important environmental factors were competitive pressures and tax/accounting rules changes, while the two most important internal factors were organizational structure and corporate strategy. With regards to ITP methods, market price or CUP ranked first for the transfer of tangible products by respondents, followed by modified market price, standard price and rate of return methods in that order. Ensuring arm's length relationship, avoiding ITP audits, global tax minimization and profit maximization were found to be the most important TP objectives of respondents.

Grubert and Mutti (1991), investigated income shifting and tax planning opportunities used by MNEs and addressed a number of international taxation issues.

Johnson and Kirsch (1991) examined the ITP objectives of US-based MNEs through a survey-based study. Questionnaires were sent to 576 US-based companies identified from the Business Week Global 1000 and Fortune 500 lists. Out of the 576, 230 companies responded of which 79 used transfer pricing in an international setting.

Borkowski (1992c) found that in relation to legally accepted TP methods, under SS 482 of the US Internal Revenue Service regulations, of the 128 useable responses received, $47 \%$ used cost plus, 33\% used comparable uncontrolled prices (CUP), while 20\% used the "fourth method". She also reported that most MNEs used their current method mainly to fulfill US legal requirements. Given the choice, the majority of the companies would shift to other methods they considered optimal.

Cravens (1997) attempted to increase the understanding of the motivating factors involved for MNEs in setting transfer pricing policies using both qualitative and quantitative measures. In addition, she explored the causal relationship beginning with the extent to which situational determinants influence transfer pricing objectives which, in turn, influence transfer pricing policy, thus influencing financial statements. She tested five main hypotheses - two on tax management, two on competitive position, and one on internal dimensions (performance evaluation, motivation and goal congruence). These hypotheses were tested on the basis of objectives rather than pricing method on the grounds that firms following different objectives might still uses similar pricing.

On the basis of her findings, Cravens stressed that transfer pricing was viewed as an effective tool in managing the tax burden.

Klassen et al (1993) attempted to examine geographic income shifting by US MNEs in relation to worldwide changes in corporate tax rates between 1984 and 1990.

Crain and Stitts (1994) compared the gross profit margin (GPM) of foreign-controlled firms operating in the US to their US-controlled counterparts.

Collins and Shackelford (1998) and Kimberly, (1998) research have tried to test the effects of taxes on cross-border payments of dividends, interest, royalties and management fees between US MNEs' foreign affiliates.

The work of Eden (2000, Nielsen, Raimondos-MYllcr and Schjelderup (2001),Bradford (2003) and Korn and Lengsfeld, (2007) have given some great insight into the complex world of transfer pricing in US. 
Cools, (2008) carried out an in-depth case study based study while Sikka and Willmott (2010) highlighted the scattered evidence to show how transfer pricing is not just an accounting technique, but also a method of resource allocation and avoidance of taxes that affects distribution of income, wealth, risks and quality of life.

Klassen, et. al. ( 2013 ) work was based on a survey of 219 MNEs. Their work shade light on the fact that MNEs are not always tax avoiders by using the transfer pricing mechanism, rather it is the strategy and policy that has adided in reduction of tax legitimately.

Similarly, the study of Hassett and Newmark (2008) has indicated it as "the practice of multinational corporations of arranging intrafirm sales such that most of the profit is made in a low-tax country." Again, two studies, one that of Jacob (1996) and other of Beuselinck and Deloof (2014) have further strengthend the above findings.

However, the revenue collectors have shown their anxiousness and concern over this sort of practice as it reduces the global tax collection (OECD 2013).

It is not necessary that the internal transfer pricing always aims at reduction of tax liability. This was observed from the work of Blouin, Robinson, Seidman (2012b).

In another interesting work, Hopland, Lisowsky, Mardan, and Schindler (2016) found that transfer pricing technique is also being used to shift profit to a loss making company from a profit making company.

The empirical study of Towery (2015) indicated that managing the international transfer pricing was the second most important work for a finance executive because of its uncertainty and unasssessable risk.

Continuing from the previuos work, Mescall and Klassen (2015) have further found that a strict transfer pricing regimn has resulted in creating more bottlenecks for cross border acquisitions.

The empirical work of De Simone (2016) analysed the OECD "arm's-length" standard on transfer pricing.

\section{CONCLUSION}

After reviewing the relevant literature on theoritical and empirical aspects of transfer pricing, it is observed that despite having so many models and empirical studies, there is no straight forward solution to the issue of international transfer pricing or the internal transfer pricing. The existing models and studies, though, help us in designing our own strategy. There is a strong need for more research and development of some standard models or formula which can be used by MNEs under all types of environments so as to reduce the mounting size of the litigations.

\section{REFERENCES}

[1] Al-Eryani, M. (1987). Policies of US Multinational Corporations on Pricing Intra comapny Transfers with Foreign Affiliates in More Developed and Less Developed Countries (Theory and Evidence), Unpublished PhD dissertation, Kent State University.

[2] Arrow, J.K. (1964). Control In Large Organisations, Management Science,10, Number 3, April, pp- 397-408.

[3] Booth, E.J.R.(1977). Transfer Prices in the global Corporation under internal and external constraints, Canadian Journal of Economics, 10, pp-434-446.

[4] Borkowski, S. C. (1992c). Section 482, Revenue Procedure 91-22, and the Realities of Multinational Transfer Pricing, International Tax Journal, spring, pp- 59-68. 
[5] Bradford, D. F. (2003). Addressing the Transfer Pricing Problem in an Origin Basis X Tax, July.

[6] Chandler, Jr.(1962). Strategy and Structure: Chapters in the History of the Industrial Enterprise, Cambridge, MIT Press,pp-480.

[7] Collins, J. H. And Shackelford, D. A.(1998). Global Organizations And Taxes: An Analysis Of The Dividend, Interest, Royalty, And management Fee Payments Between US Multinational's Foreign Affiliates, Journal of accounting and Economics, 24, pp151-173.

[8] Cools, M. (2008). Transfer Pricing and the Management Control System in the Tax Complient Multinational Enterprise, July.

[9] Copithorne, L.W.(1971). International Corporate transfer Prices And Government Policy, Canadian, Journal of Economis, 10, pp- 434-446.

[10] Crain, T. L. and Stitts, R. H.(1994). A Comparison of Gross Profit Margins Between Foreign-controlled Domestic Corporations and Comparable US-controlled Domestic Corporations, Journal of international Accounting, Auditing and taxation, 3(1), pp- 85101.

[11] Cravens, K. S. (1997). Examining the Role of Transfer Pricing as a Strategy for Multinational Firms, International Business Review, vol. 16, no.2, pp- 127-145.

[12] Eccles,R.G.(1985). The Transfer Pricing Problem: A Theory for Practice , Lexington, MA: Lexington Books.

[13] Eden, L. (1998). Taxing multinationals: Transfer pricing and corporate Income taxation In North America. First Edition.

[14] Ernst and Young,(1991). Business International Corporation.

[15] Grabski, S.,(1985). Transfer Pricing in Complex Organizations: A Review and Integration of Recent Empirical and Analytical Research, Journal of Accounting Literature , 4, pp- 3375.

[16] Grubert, H. and Mutti, J. (1991). Taxes, Tariffs and Transfer Pricing in Multinational Corporate Decision Making, The Review of Economics and Statistics, 73, May, pp- 285293.

[17] Harris, Kriebel , M. C. and Raviv, A.(1982). Asymmetric Information, Incentives and Intrafirm Resource Allocation, Management Science ,June pp- 604-620.

[18] HirshIeifer, J. (1957). Economics of the divisionalized firm. Journal of Business, 30, pp96-108.

[19] Hirshleifer, J. (1956). On the Economics of Transfer pricing, The Journal of Business, July, pp- 172.

[20] Ismail, B.,(1982). Transfer Pricing under Demand Uncertainty," Review of Business and Economic Research, pp-1-14.

[21] Jensen, O.W.(1986). Transfer Pricing and output decisions: the dynamic interaction, Decision Sciences 17, Summer, pp-428-436.

[22] Johnson, W. A. and Krisch , R. J. (1991). International Transfer Pricing and Decision Making in United States Multinationals, International Journal of Management, 8, no. 2, pp- 554-561.

[23] Kanodia, C.(1979). Risk Sharing and Transfer Price Systems under Uncertainty, Journal of Accounting, 17, pp-74-98.

[24] Kaplan, R.(1982). Advanced Management Accounting (Prentice-Hall).

[25] Kim, S. H. and Miller, S. W. (1979). Constituents of the International Transfer Pricing Decisions, Columbia Journal of World Business, 14, no. 1, Spring, pp- 69-77.

[26] Kim, W. S. and Lyn , E. O. (1990). FDI Theories and the Performance of Foreign Multinationals Operating in the US, Journal of International Business Studies, Frist Quarter, pp- 41-54. 
[27] Klassen, K., Lang, M. and Wolfson , M. (1993). Geographic Income Shifting by Multinational Corporations in Response to Tax Rate Changes, Journal of Accounting Research,31, pp-141-173.

[28] Klassen, K., Lisowsky, P. and Mescall, D.(2013). Transfer Pricing : strategies, Practices, and Tax Minimization.

[29] Korn, E., \& Lengsfeld, S. (2007). Duopolistic Compitition, Taxes, and Arm's Length Principle, July.

[30] Nielsen, S. B., Raimondos-MYller, P., \& Schjelderup, G. (2001). Formula Apportionment and Transfer Pricing Under Oligopolistic Competition, May.

[31] Sikka, P., \& Willmott, H. (2010). The Dark Side of Transfer Pricing; Its role in the Tax Avoidance and Wealth Retentiveness, February.

[32] Solomons,D.(1965). Divisional Performance Measurement and Control, Homewood, IL:R.D.Irwin.

[33] Tang, R.Y. W. and Chan, K. H. (1979). Environmental Variables Of International Transfer Pricing: A Japan-United States Comparison, Abacus, 15, June, pp- 3-12.

[34] Vancil, R.F.(1979). Decentralisation: Managerial Ambiguity by Design, Homewood,IL:Dow jones-Irwin.

[35] Wheeler, J. E. (1988). An Academic Look at Transfer Pricing in a Global Economy, Tax Notes, July 4, pp-87-96. 